\title{
O Ministério Público na defesa do Regime Democrático e sua imprescindível atuação no Processo Eleitoral
}

\author{
The Public Ministry in defense of the Democratic Regime and its \\ performance in the Electoral Process
}

\author{
Tarsis Barreto Oliveira ${ }^{1}$ \\ André Ricardo Fonseca Carvalho ${ }^{2}$
}

\begin{abstract}
RESUMO
O presente trabalho analisa os principais tópicos e o regramento constitucional e legal sobre as funções do Ministério Público na defesa do regime democrático. O papel do Ministério Público ganha relevância com sua atuação perante todos as etapas do processo eleitoral, cabendo-lhe zelar por uma eleição hígida, de forma a se respeitar a verdadeira vontade dos eleitores das diferentes localidades do país, sem que haja contaminação no processo eleitoral de diferentes abusos de ordem política, econômica ou de outra espécie. O método descritivo mostra-se mais adequado para a análise do estudo proposto. $\mathrm{O}$ resultado da pesquisa apresenta a necessidade de se garantir ao Ministério Público a possibilidade de efetivo exercício de suas funções para se alcançar o respeito ao sistema democrático.
\end{abstract}

\section{PALAVRAS-CHAVE:}

Ministério Público; democracia; eleições.

\begin{abstract}
This work analyzes the main topics and the constitutional and legal rules on the functions of the Public Prosecutor's Office in defense of the democratic regime. The role of the Public Prosecutor's Office gains relevance with its performance in all stages of the electoral process, being responsible for a healthy election, in order to respect the true will of the voters of the different localities of the country, without contamination in the electoral process of different abuses of political, economic or other kind. The descriptive method is more suitable for the analysis of the proposed study. The result of the study presents the need to guarantee to the Public Prosecutor's Office the possibility of effective exercise of its functions to achieve respect for the democratic system.
\end{abstract}

\footnotetext{
${ }^{1}$ Doutor e Mestre em Direito pela UFBA. Professor Associado de Direito da UFT. Professor Adjunto de Direito da UNITINS. Professor do Mestrado em Prestação Jurisdicional e Direitos Humanos da UFT/ESMAT. Membro do Comitê Internacional de Penalistas Francófonos e da Associação Internacional de Direito Penal. E-mail: tarsisbarreto@uft.edu.br.

${ }^{2}$ Promotor de Justiça no Estado do Tocantins. Promotor de Justiça da Vara de Execução Penal de Porto NacionalTO. Especialista em Ciências Penais (UNISUL). Especialista em Estado de Direito e Combate à Corrupção (ESMAT). Mestrando em Prestação Jurisdicional e Direitos Humanos da UFT/ESMAT. E-mail: andrecarvalho@mpto.mp.br.
} 


\section{KEYWORDS:}

Public Prosecutor's Office; democracy; elections.

\section{INTRODUÇÃO}

O presente trabalho promove estudo sobre as funções essenciais conferidas ao Ministério Público na Constituição da República de 1988, em especial a defesa do regime democrático. Surgem, a partir da Constituição de 1988, os principais vértices de atuação do Ministério Público, recebendo tratamento de instituição essencial à função jurisdicional do Estado.

Inicia-se, assim, a análise da formação do Estado, até a previsão constitucional do Estado Democrático de Direito. Como o pilar da constituição do Estado brasileiro, torna-se imprescindível a análise das características do regime democrático previsto em nosso país.

O processo eleitoral faz parte da garantia do regime democrático, tendo o Ministério Público papel fundamental em todo o processo para garantia de eleições sem abusos, que possam macular a verdadeira intenção de voto dos cidadãos.

O estudo apresenta relevância em virtude da contemporaneidade da matéria, pois o Brasil está diante de seu maior desafio eleitoral em virtude de o processo coincidir com uma crise sanitária sem precedentes, considerando-se ainda o processo de amadurecimento de sua renovada democracia.

\section{ESTADO DEMOCRÁTICO DE DIREITO NO BRASIL}


Estado, em uma concepção moderna, é considerado uma ordenação que possui como fim específico e essencial a regulamentação global das relações sociais entre membros de uma dada população em dado território. (PALLIERI, 1955, p. 14)

Consoante essa clássica corrente doutrinária, para configuração do Estado deve existir uma figura de poder soberano, além de um povo fixado dentro de um território, havendo finalidade específica.

Houve, ao longo da história, uma evolução conceitual de Estado, até chegarmos à atual previsão constitucional do Estado Democrático de Direito, considerado, por muitos autores, como uma síntese dos conceitos de Estado previamente formulados.

A divisão que prepondera atualmente recai sobre o Estado Moderno e Contemporâneo. Antes, porém, de acordo com a evolução cronológica apresentada por alguns autores, há de se destacar o Estado Antigo, Estado Grego, Estado Romano e Estado Medieval.

Estado Antigo, Oriental ou Teocrático são as formas de Estado mais recuadas no tempo, perpassando as antigas civilizações do Oriente e do Mediterrâneo. Tinham como características principais a religiosidade, com uma estreita relação entre Estado e a divindade, e a natureza unitária, com uma unidade geral, sem fragmentações. (DALLARI, 1995, p. 53)

Estado Grego refere-se às características presentes de forma comum entre os diferentes povos helênicos. Caracteriza-se pela cidade-Estado, no qual, segundo a perspectiva aristotélica, o homem é feito para a sociedade política. Nessa perspectiva, o homem é um animal social, o que o torna essencialmente um ser citadino. Para Aristóteles, a estratégia de partir de comunidades menores para maiores atende, apenas, ao seu método de decompor a realidade dada em elementos inferiores, a fim de melhor compreendê-la. Na verdade, o que ele pretende apresentar é que a polis é natural, ou seja, está na natureza e que, acima de tudo, precede suas partes. (BARROS, 2009, p. 23)

O Estado Romano destacou-se por uma intensa expansão de domínio territorial pelo mundo, com duração de mais de um milênio. Uma de suas características mais marcantes é a base familiar de organização, e durante um período o povo participava diretamente do governo, em que pese ser restrita a noção de povo, que compreendia apenas uma faixa estrita da população, tendo como governantes supremos os magistrados. (DALLARI, 1995, p. 55) 
Por fim, o Estado Medieval caracteriza-se por sua heterogeneidade e instabilidade, sendo precursor do Estado Moderno. Os seus principais elementos formadores residem no Cristianismo, base da aspiração à universalidade, com estímulo à unidade política; nas invasões bárbaras, entre os séculos III e VI, caracterizando-se pelas incursões armadas pelo território do Império Romano; e no feudalismo, com toda vida social passando a depender da propriedade ou da posse da terra, desenvolvendo-se um sistema administrativo e uma organização militar entrelaçados à situação patrimonial. (DALLARI, 1995, p. 56-58)

Chega-se, então, após essa breve exposição cronológica, ao Estado Moderno, que possui como características materiais o território e o povo, além de elementos vinculados ao poder e à finalidade, que se refere à disposição das pessoas de integrarem uma ordem e viverem em virtude de um fim a ser atingido.

De acordo com os ensinamentos de Diaz (2007, p. 6-7):

A nosso ver, será Thomas Hobbes o primeiro teórico do Estado Moderno, pois fará a
separação entre a pessoa do governante e o Estado, e deste, com a religião. A
finalidade de Hobbes com sua filosofia política é fundamentar solidamente o poder
civil em uma época em que era vigorosa a ideologia do direito natural e a melhor
maneira então de fundar o poder civil era demonstrar que a obediência ao soberano
constituía uma obrigação derivada de uma lei natural. Segundo sua Teoria, uma vez
constituído o Estado não há para os súditos, salvo exceções bem delimitadas, outra
obrigação natural (ou moral), além daquela. Defendia o máximo de soberania
compatível com o mínimo de resistência.

O Estado Moderno destaca-se no continente europeu entre os séculos XII e XVIII, com concentração de poder político nas mãos de uma realeza, de forma independente da igreja. Garantem-se, por esse modelo, os direitos ligados à liberdade e à individualidade, consagrandose os denominados direitos fundamentais de primeira geração.

Por fim, há de se ressaltar o aparecimento da última classificação sobre o Estado, com o denominado Estado Contemporâneo.

Em razão do desenvolvimento da sociedade e os conflitos das relações sociais, sobretudo, por todas as modificações estabelecidas ao longo do tempo pelo capitalismo, passase, então, a existir uma luta por reconhecimentos de direitos, sobretudo de ordem social.

Diversas circunstâncias causaram transformações na estrutura estatal para ocorrência da transformação do Estado Moderno no Estado Contemporâneo. Destacam-se, entre outros, os 
seguintes elementos: a organização do capitalismo com a modificação da livre concorrência de mercado; a racionalidade do poder legal, entendido como modo de transmissão de comando concreto; os movimentos sociais que eclodiram a partir da segunda metade do século XIX, ainda no seio do Estado Moderno; e, ainda, as novas concepções que impressionaram o pensamento político. (BRANDÃO, 2001, p. 41).

Observa-se toda essa evolução através da verificação das contradições sociais existentes no sistema liberal, tentando-se, assim, acomodar os interesses da sociedade capitalista com as desigualdades sociais, passando o Estado a adquirir novas funções, partindo-se para um Estado de bem-estar.

Há de se destacar a existência de algumas classificações na busca desse Estado, com prevalência de diferentes modelos de variação a depender do período histórico, das diferentes localidades e do grau de desenvolvimento econômico de diferentes países.

Destaca-se, nessa classificação, o Estado de bem-estar liberal, onde há intervenção mínima do Estado em relação aos direitos sociais, havendo estímulo ao mercado e garantia dos direitos de liberdade, com dualismo de classe; Estado de bem-estar corporativista, com garantia de direitos às novas classes a partir da situação pós-industrial. Há uma maior intervenção estatal sobre a atividade econômica, porém, com consolidação do status social existente através de políticas sociais retributivas de forma subsidiária; e Estado de bem-estar social democrático, com serviços prestados pelo Estado voltados principalmente para a classe média, com o objetivo de reduzir a desigualdade social. (DIAZ, 2007, p. 15-16):

Após essa resumida digressão histórica, cabe a análise do Estado brasileiro a partir da Constituição da República de 1998.

A Constituição da República adotou de forma conceitual de seu regime o Estado Democrático de Direito, ao estabelecer em seu artigo 1: "A República Federativa do Brasil, formada pela união indissolúvel dos Estados e Municípios e do Distrito Federal, constitui-se em Estado Democrático de Direito (...)".

Verifica-se, dessa forma, uma junção dos princípios norteadores do Estado Democrático e do Estado de Direito. 
O Estado de Direito, em sua concepção inicial, refere-se a conceitos de um Estado Liberal, com observância aos pressupostos legais, havendo divisão de poderes e com observância de garantia dos direitos individuais. Após, passou-se ao Estado Social de Direito, com previsão de direitos sociais, buscando-se alcançar a justiça social. Já o Estado Democrático caracteriza-se pelo componente de soberania popular, baseando-se no princípio democrático como garantidor de direitos fundamentais.

De acordo com os ensinamentos de SILVA (2000, p. 123):

\begin{abstract}
A configuração do Estado Democrático de Direito não significa apenas unir formalmente os conceitos de Estado Democrático e Estado de Direito. Consiste, na verdade, na criação de um conceito novo, que leva em conta os conceitos dos elementos componentes, mas os supera na medida em que incorpora um componente revolucionário de transformação do status quo. E aí se entremostra a extrema importância do art. $1^{\circ}$ da Constituição de 1988, quando afirma que a República Federativa do Brasil se constitui em Estado Democrático de Direto, não como mera promessa de organizar tal Estado, pois a Constituição aí já o está proclamando e fundando.
\end{abstract}

Há aqui a necessidade de serem seguidas as normas democráticas, com realização de eleições, além de serem respeitados os direitos por parte de quem detém o poder.

A Constituição brasileira elevou o país à condição de Estado Democrático de Direito, com uma convergência de vontades entre aqueles que são legalmente administrados, ou seja, o povo, e aqueles que legitimamente administram, isto é, o governo. Como consequência disso, o regime de governo ou regime político evoluiu de uma democracia meramente representativa para um regime democrático participativo ou semidireto, onde ser cidadão não significa apenas a posse lícita de um título de eleitor, visto que a cidadania ganha novo relevo conceitual. Nos termos do art. $1^{\circ}$, parágrafo único, a cidadania implica participação ativa na vida política do Estado, não apenas através do voto direto, secreto, periódico e universal, que, inclusive, constitui cláusula inviolável, mas, ainda, na atuação junto ao poder público através de instrumentos constitucionais, como o plebiscito, o referendo, a iniciativa popular e a ação popular, entre outros. (FILHO; SANTOS, 2000, p. 31)

Alguns princípios são observados para se caracterizar o Estado Democrático de Direito, destacando-se o princípio da constitucionalidade, em que o Estado se funda na legitimidade de uma constituição rígida, emanada da vontade popular e com vinculação dos poderes; princípio democrático, configurando-se por uma democracia representativa, participativa, pluralista, com garantia de vigência e eficácia dos direitos fundamentais; sistemas de direitos fundamentais; 
princípio da justiça social, em que se abre para realização da democracia social e cultural, sem avançar significativamente rumo à democracia econômica; princípio da igualdade; da divisão dos poderes e da independência do juiz; da legalidade e da segurança jurídica. Há de se destacar, por fim, que sua tarefa fundamental consiste em superar as desigualdades sociais e regionais e instaurar um regime democrático que realize justiça social. (SILVA, 2000, p. 126)

\section{MiNistério PÚBlico E SUA ATUAÇÃo NA DEFESA DO REGIME DEMOCRÁTICO}

O Ministério Público brasileiro, como instituição, surgiu apenas na República, pois nos períodos coloniais e imperiais os procuradores do rei eram simples representantes dos interesses da Coroa. Com a proclamação da República, coube a Campos Salles, na qualidade de Ministro da Justiça do Governo Provisório, fazer com que o Ministério Público brasileiro ganhasse contornos de instituição. (MAZZILLI, 1997, p. 1)

Ao longo das diferentes Constituições do período republicano brasileiro, houve a previsão da organização do Ministério Público sem muitas alterações ao longo do tempo. Contudo, alterações legislativas ordinárias, principalmente no campo processual penal, bem como no processual civil, além da proteção dos interesses difusos, foram dando contornos à instituição e às suas funções.

No período anterior à Constituição de 1988, alguns movimentos institucionais, principalmente nas décadas de 1970 e 1980 por parte de promotores e procuradores de justiça, tiveram o condão de apresentar proposições para o que seria a configuração do Ministério Público na Constituição da República.

A partir de Congressos Nacionais do Ministério Público, nos anos de 1985 e 1986, este ocorrido na capital paranaense, de onde se elaborou a Carta de Curitiba, são formuladas importantes contribuições para a evolução da instituição. Outro fato relevante foi a instauração, no ano de 1985, da Comissão Provisória de Estudos Constitucionais, cuja presidência ficou ao encargo de Afonso Arinos, para cumprir a promessa de redemocratização do País e preparar 
um anteprojeto que deveria servir de texto básico para a elaboração da nova Constituição Federal. No anteprojeto entregue, restaram incorporadas diversas das ideias constantes da Carta de Curitiba. Estes textos inspiraram o texto constitucional vigente e consolidaram a intensa luta no sentido de transformar o Ministério Público de apêndice do Poder Executivo em instituição permanente, essencial à função jurisdicional do Estado, independente e autônoma. (DIAZ, 2007, p. 76-77)

A atual Constituição da República tratou-o em sessão especial, separado dos demais poderes do Estado, com um capítulo dentro das funções essenciais à Justiça, estabelecendo, em seu artigo 127, que o Ministério Público é instituição permanente, essencial à função jurisdicional do Estado, incumbindo-lhe a defesa da ordem jurídica, do regime democrático e dos interesses sociais e individuais indisponíveis. (BRASIL, 1988)

Verifica-se no tratamento constitucional dado ao Ministério Público sua vocação de defesa da sociedade, funcionando como um intermediador das relações de interesse da sociedade.

Nesse prisma, cabe destacar as palavras de Goulart (1998, p. 96):

Integrando a sociedade civil, o Ministério Público, nos limites de suas atribuições, deve participar efetivamente do 'processo democrático', alinhando-se com os demais órgãos do movimento social comprometidos com a concretização dos direitos previstos e a positivação de situações novas que permitam o resgate da cidadania para a maioria excluída desse processo, numa prática transformadora orientada no sentido da construção da nova ordem, da nova hegemonia, do 'projeto democrático'.

Importante notar que a Constituição de 1988 coloca o Ministério Público em capítulo especial, fora da estrutura dos demais poderes da República, consagrando sua total autonomia e independência e ampliando-lhe as funções (arts. 127/130), sempre em defesa dos direitos, garantias e prerrogativas da sociedade. (MORAES, 2006, p. 544)

Diferentes correntes doutrinárias tentaram delimitar a posição do Ministério Público perante o texto constitucional. Para alguns doutrinadores, o Ministério Público estaria vinculado ao Poder Legislativo, sobretudo em sua atuação de efetiva fiscalização do cumprimento da lei. Para outra corrente, o Ministério Público possui, precipuamente, função jurisdicional, e assim estaria ligado ao Poder Judiciário. Por fim, há posicionamentos doutrinários que defendem ser as funções do Ministério Público de caráter administrativo, no sentido de sua atuação estar atrelada à execução das leis e, portanto, ligado ao Poder Executivo. 
Contudo, nenhuma dessas concepções encontra amparo no Texto Constitucional de 1988 que, além de ampliar muito o campo de atribuição do Ministério Público, conferiu-lhe autonomia administrativa, orçamentária e funcional(art. 127, $\S 2^{\circ}$, da CF), colocou-o em capítulo separado dos outros Poderes do Estado, traçou os seus princípios institucionais (art. $127, \S 1^{\circ}$, da $\mathrm{CF}$ ) e, ainda, conferiu garantias funcionais aos seus órgãos de execução para o exercício independente do mister constitucional (art. 128, § 5, inciso I, alíneas "a", "b" e "c"). (ALMEIDA, 2008, p. 12)

Sobre o posicionamento constitucional do Ministério Público, relevantes os ensinamentos de Mazzilli (1991, p. 40-41):

\begin{abstract}
Ao contrário, muito mais adequada foi a solução encontrada na Constituição de 1988. Como se viu e é bem sabido, a divisão tripartite do Poder é antes política e pragmática que científica. Ora, na verdade, pouca ou nenhuma importância teria colocar o Ministério Público dentro de qualquer Poder do Estado, ou até utopicamente erigi-lo a um quarto Poder (como queria Valladão), a fim de que, só por isso, se pretendesse conferir-lhe independência. Esta não decorrerá basicamente da colocação do Ministério Público neste ou naquele título ou capítulo da Constituição, nem de denominá-lo Poder de Estado autônomo ou não; antes, primordialmente, dependerá das garantias e instrumentos de atuação conferidos à instituição e a seus membros. E, naturalmente, dos homens que a integrem. De qualquer forma, porém, como já antecipamos, a solução que sempre nos pareceu a melhor, justamente para contribuir de forma pragmática para esse desiderato de autonomia e independência da instituição, não era erigir o Ministério Público a um suposto "quarto Poder", nem colocá-lo dentro dos rígidos esquemas da divisão tripartite atribuída a Montesquieu, mas sim a de inseri-lo em título, capítulo ou seção própria. A nosso ver, melhor fora, até, colocá-lo lado a lado com o Tribunal de Contas, entre os órgãos de fiscalização e controle das atividades governamentais, ou, como já o fizera a Constituição de 1934, entre os "órgãos de cooperação nas atividades governamentais" (arts. 95 a 98). A Constituição de 1988 praticamente atendeu, nesse passo, a essa aspiração, colocando o Ministério em Seção própria do Capítulo IV - "Das funções essenciais à Justiça", do Título IV - "Da Organização dos Poderes", ou seja, solução semelhante à das Constituições de 1934 e 1946, e não mais no Capítulo do Poder Executivo (como ocorrera na Carta de 1969), nem no do Poder Judiciário (como na CF de 1967), nem no do Poder Legislativo (como sustentam alguns).
\end{abstract}

Com a Constituição da República de 1998 fica estabelecida plena importância de atuação do Ministério Público perante o Estado Democrático de Direto, com a previsão da defesa do regime democrático.

Democracia deve ser concebida através de um conceito histórico, não podendo ser considerada como um valor fim, mas meio e instrumento de realização de valores essenciais de convivência humana, que se traduzem basicamente nos direitos fundamentais do homem. Compreende-se que a historicidade destes a envolva na mesma medida, enriquecendo-lhe o conteúdo a cada etapa do evolver social, mantido sempre o princípio básico de que ela revela 
um regime político em que o poder repousa na vontade do provo. Sob esse aspecto, a democracia não é um mero conceito político abstrato e estático, mas é um processo de afirmação do povo de garantia dos direitos fundamentais conquistados no decorrer da história. (SILVA, 2000, p. 129-130)

Há de se reconhecer a democracia como princípio constitucional normativo, não se tratando, simplesmente, de uma regra de maioria.

Em vista da evolução já alcançada pelo Estado e pelos Direitos Humanos, hoje positivados e denominados direitos fundamentais, a democracia deve ser entendida como um complexo sistema de regras e procedimentos orientados por diretrizes axiológicas, ou seja, como conjunto de ideias, princípios éticos e políticos que ordena a vida dos cidadãos perante o Estado, com preservação da dignidade da pessoa humana. Dessa forma, a Constituição deve ser tomada como um documento vinculante, um instrumento que determina a todos, cidadãos, sociedade civil e governo, o cumprimento de suas determinações. (DIAZ, 2007, p. 82)

A existência de uma democracia legítima pressupõe longo caminho a ser trilhado, um caminho de efetivo exercício da própria democracia, o que não exclui a necessidade de um sistema constitucional legítimo que assegure: a) a divisão do poder (quem faz a lei não é quem julga nem a aplica; quem a aplica não a faz nem julga; quem julga, não é quem a faz nem a aplica); b) o controle da separação do poder (não basta a Constituição dizer que o poder é repartido; é necessário que existam mecanismos de freios e contrapesos, e que estes mecanismos funcionem efetivamente); c) o reconhecimento de direitos e garantias individuais e coletivos; d) o respeito à liberdade e à igualdade das pessoas, bem como à dignidade da pessoa humana; e) a existência de decisões tomadas direta ou indiretamente pela maioria, respeitados sempre os direitos da minoria; f) a total liberdade na tomada de decisões pelo povo; g) um sistema eleitoral livre e apto para recolher a vontade expressa pelos cidadãos; h) o efetivo acesso à alimentação, à saúde, à educação, ao trabalho, à justiça e demais condições básicas de vida por parte de todos. (MAZZILLI, 1997, p. 11)

Diante dessa formatação concebida ao Ministério Público, foram estabelecidos direitos e garantias para seu pleno funcionamento, com possibilidade de desempenho de um serviço de excelência ao longo dos anos, mesmo que muito ainda há de ser construído na busca de uma sociedade mais justa. 
Nesse ponto, o Ministério Público, com a Constituição de 1998, passou a ser Instituição permanente, de caráter nacional, una, indivisível, instituída para a defesa da ordem jurídica, do regime democrático e dos interesses fundamentais da sociedade. Assim, se o Ministério Público é defensor do regime democrático e, se a República Federativa do Brasil se constitui em um Estado Democrático de Direito, o Ministério Público tornou-se, com a atual Constituição, Instituição constitucional fundamental do Estado Democrático de Direito. Todas as diretrizes do Estado Democrático de Direito, tais como a priorização da tutela jurídica preventiva, a tutela jurídica ampla e irrestrita a direitos individuais e coletivos, a transformação da realidade social, entre outras, são os legítimos parâmetros que delineiam o Ministério Público no contexto constitucional atual. (ALMEIDA, 2007, p. 11)

Para bom desempenho de suas funções e alcance das diretrizes determinadas pela Constituição da República, há previsão, como princípios institucionais, nos termos do art. 127, a unidade, a indivisibilidade e a independência funcional do Ministério Público. E, ainda, no art. $128, \S 5^{\circ}$, I, ficaram expressas as garantias do Ministério Público, como vitaliciedade após dois anos de exercício; inamovibilidade, salvo por motivo de interesse público; e irredutibilidade de subsídios.

De acordo com Mazzilli (1997, p. 8-9):

\begin{abstract}
A defesa do regime democrático pelo Ministério Público deve fazer-se em dois níveis, com desdobramentos que adiante apontaremos: a) controle de constitucionalidade das leis que violem princípio constitucional, a ser feito sob forma concentrada (especialmente por meio da propositura de ações diretas de inconstitucionalidade, de representações interventivas e de algumas ações civis públicas para defesa de interesses difusos); b) controle de constitucionalidade das leis que violem princípio constitucional, a ser feito sob forma difusa, caso a caso, impugnando-se as medidas e atos concretos que violem uma norma constitucional (especialmente por meio da ação penal, do inquérito civil e da ação civil pública para defesa de interesses sociais, difusos, coletivos e individuais homogêneos, além de outros mecanismos de fiscalização e controle afetos à instituição).
\end{abstract}

Importante ponto a destacar é que o regime democrático é cláusula pétrea, nos termos do art. 60, $\S 4^{\text {o }}$, incisos II e IV, da Constituição de 1988, concluindo-se, assim, que o Ministério Público, como instituição designada a defender o regime democrático, também deve ser considerado como incurso neste rol.

Nesse sentido, discorre Garcia (2005, p. 47): 
Além da necessária adequação material que deve existir entre referido preceito e a legislação infraconstitucional, o fato de o Constituinte originário ter considerado o Ministério Público uma Instituição permanente e essencial à função jurisdicional do Estado traz reflexos outros, limitando, igualmente, o próprio poder de reforma da Constituição. Com efeito, partindo-se da própria natureza da atividade desenvolvida pelo Ministério Público, toda ela voltada ao bem-estar da coletividade, protegendo-a, em especial, contra os próprios poderes constituídos, a sua existência pode ser considerada como ínsita no rol dos direitos e garantias individuais, sendo vedada a apresentação de qualquer proposta de emenda tendente a aboli-la (art. 61, § $4^{\circ}$, IV, da $\mathrm{CF} / 1988)$

\title{
4. O PAPEL DO MINISTÉRIO PÚBLICO NO PROCESSO ELEITORAL
}

O preâmbulo e o art. $1^{\circ}$ da Constituição da República consagraram o princípio democrático como o regime político brasileiro. O parágrafo único do art. $1^{\circ}$ estabelece que todo o poder emana do povo, que o exerce por meio de representantes eleitos ou diretamente, nos termos desta Constituição, não havendo dúvidas, assim, que foi instituído o regime democrático fundado na soberania popular.

De acordo com Silva (2000, p. 135-136):

\begin{abstract}
A democracia, em verdade, repousa sobre dois princípios fundamentais ou primários, que lhe dão a essência conceitual: (a) o da soberania popular, segundo o qual o povo é a única fonte do poder, que se exprime pela regra de que todo o poder emana do povo; (b) a participação direta ou indireta, do povo no poder, para que este seja efetiva expressão da vontade popular; nos casos em que a participação é indireta, surge um princípio derivado ou secundário: o da representação. As técnicas que a democracia usa para concretizar esses princípios têm variado, e certamente continuarão a variar, com a evolução do processo histórico, predominando, no momento, as técnicas eleitorais com suas instituições e o sistema de partidos políticos, como instrumentos de expressão e coordenação da vontade popular. A igualdade e liberdade, também, não são princípios, mas valores democráticos, no sentido de que a democracia constitui instrumento de sua realização no plano prático. A igualdade é o valor fundante da democracia, não a igualdade formal, mas a substancial.
\end{abstract}

Adota-se, no Brasil, a combinação entre democracia representativa e a participação direta, nos termos do art. $1^{\circ}$, parágrafo único, da Constituição da República. Todavia, há de se destacar, por todas as características nacionais, a importância, neste tópico, da democracia representativa. 
Trata-se do tipo de democracia conhecida como indireta, na qual o povo, impossibilitado de exercer diretamente a gestão do Estado, outorga essa função a alguns representantes, mediante eleições periódicas.

Uma democracia representativa só funciona adequadamente mediante um sistema efetivo de partidos, com programas de governo - para que a vontade dos eleitores não seja burlada pelos eleitos que queiram trair os compromissos e programas partidários que foram usados para captar os votos dos eleitores. Por isso, faz parte da democracia, além do pluripartidarismo, a necessidade de fidelidade aos compromissos e programas de partido. (MAZZILLI, 1997, p. 11-12)

Para o estabelecimento de um governo popular, as eleições constituem uma condição necessária, mas que, por si só, não é suficiente. A democracia, evidentemente, não pode ser resumida aos atos de votar e ser votado. O verdadeiro alcance do experimento democrático supera a conquista do direito de sufrágio, uma vez que rompe a garantia de participação na formação do poder para atingir um estágio em que a atuação governamental lhe oferece um retorno, identificado pelo oferecimento de uma sociedade em que se compartam os demais direitos considerados fundamentais. Há de se buscar não apenas o aspecto representativo, mas também o amplo desenvolvimento social. (ALVIM, 2014, p. 27)

Contudo, para serem alcançados os princípios democráticos, certo é que o processo eleitoral tem fundamental importância para a efetiva concretização da democracia. Não se pode olvidar que o processo eleitoral, de maneira isolada, não garante o processo democrático de um país, havendo a possibilidade, por exemplo, de um regime ditatorial valer-se de um processo eleitoral para se manter no poder.

Nesse ponto, a realização de eleições não conduz, necessariamente, ao reconhecimento instantâneo de um regime verdadeiramente democrático. Considerada a democracia em seu aspecto amplo e substancial - a demandar, além da participação na formação do poder, o acesso a um mínimo de liberdade e justiça social -, a adoção da mecânica eletiva tende a proporcionar um governo democrático sob o ângulo da origem, sendo, de consequência, de caráter procedimental. Porém, importa notar que, se a simples execução de pleitos não garante, isoladamente, uma democracia em sua feição integral, vezes há em que o desenvolvimento de 
eleições sequer assegura a construção do pilar que lhe toca na edificação de um sistema de governo popular. (ALVIM, 2014, p. 29)

Dessa forma, torna-se primordial a participação do Ministério Público, em seu conteúdo fiscalizatório, nas eleições brasileiras, como forma de se aproximar ao máximo possível de um verdadeiro e cristalino processo democrático, garantindo-se a lisura e higidez dos pleitos eleitorais.

O exercício de suas funções tendo em conta a tutela da democracia, a regularidade do processo eleitoral e a proteção dos direitos humanos são, para além do impulso renovador dado pela tutela dos interesses difusos e coletivos, aspectos de acentuada valorização do Ministério Público como tutor no Estado Democrático de Direito do regime democrático e da ordem jurídica. (JUNIOR, 2002, p. 2)

Sobre o papel constitucional do Ministério Público, observa-se que no conceito de ordem jurídica encontram-se situados os direitos fundamentais, verdadeiras cláusulas pétreas protegidas contra a erosão legislativa. Sobre a defesa do regime democrático, a atuação abrange todas as fases do processo eleitoral, velando pelo respeito à vontade popular na escolha dos seus mandatários, o que habilita a Instituição a receber o título de fiadora da democracia. Já em relação à defesa dos interesses sociais, o Ministério Público tem o poder-dever de atuar nas causas que envolvam direitos individuais homogêneos, coletivos e difusos, área na qual são constantes os conflitos que alcançam bens jurídicos de grupos menos favorecidos, discriminados, em condição de hipossuficiência ou ainda em situação de risco. (AGUIAR, 2009, p. 5):

$\mathrm{O}$ art. 128 da Constituição da República traz a abrangência do Ministério Público brasileiro, compreendendo, em seu inciso I, o Ministério Público da União, formado por: a) o Ministério Público Federal; b) o Ministério Público do Trabalho; c) o Ministério Público Militar; d) o Ministério Público do Distrito Federal e Territórios. Já o inciso II do mesmo artigo traz a previsão dos Ministérios Públicos dos Estados.

Observa-se, assim, que o Ministério Público Eleitoral não tem uma carreira específica, possuindo uma formação mista, sendo integrado por membros do Ministério Público Federal e do Ministério Público Estadual, cabendo ao primeiro, através do Procurador-Geral Eleitoral 
(PGR), e Vice-Procurador-Geral Eleitoral atuarem perante o Tribunal Superior Eleitoral e os Procuradores Regionais Eleitorais atuarem perante os Tribunais Regionais Eleitorais. Em relação ao segundo, os Promotores Eleitorais atuam perante os Juízes Eleitorais e as Juntas Eleitorais. Pode-se falar que a função eleitoral, desempenhada pelo Ministério Público, tem natureza federal. $\mathrm{O}$ art. 78 da Lei Complementar n. 75/1993 estabelece que as funções eleitorais do Ministério Público Federal perante os Juízes e Juntas Eleitorais serão exercidas pelo Promotor Eleitoral, integrante do Ministério Público Estadual. (LENZA, 2012, p. 841-842)

Conforme ensinamentos de Garcia (2015, p. 600):

Na dicção do art. $1^{\circ}$, caput, da Constituição da República, a República Federativa do
Brasil é um Estado Democrático de Direito. A democracia, princípio fundamental do
Estado brasileiro, se efetiva a partir da concreção dos mecanismos destinados a
assegurar o liberalismo político, permitindo a participação do verdadeiro detentor do
poder nos destinos do Estado. Além de versar sobre os instrumentos implicitamente
destinados à preservação da democracia, a Constituição da República, em seu art. 127 ,
caput, dispôs, de forma expressa, que ao Ministério Público incumbe a defesa do
regime democrático. Esse mandamento, aliás., foi repetido pelo art. $1^{\circ}$ da Lei $\mathrm{n}^{\circ}$
8.625/93. Uma das formas mais basilares de cumprimento desse dever institucional,
estando nele implícita, reside na utilização de todos os meios necessários para
assegurar a normalidade e a legitimidade do procedimento eletivo. Nesse sentido, é
expresso o art. 72 , caput, da Lei Complementar n $\mathrm{n}^{\circ} 75 / 93$ : "Compete ao Ministério
Público Federal exercer, no que couber, junto à Justiça Eleitoral, as funções do
Ministério Público atuando em todas as fases e instâncias do processo eleitoral".
Apesar de inerente ao Ministério Público Federal, o exercício da função eleitoral,
perante os Juízes e Juntas Eleitorais, é outorgado aos Promotores de Justiça, na
condição de Promotores Eleitorais (art. 78 da Lei Complementar no $\mathrm{n}^{\circ} 75 / 93$ ).

O Ministério Público, diante de seu perfil constitucional, deve dirigir todos os esforços frente às suas atribuições eleitorais, como forma de garantir a realização do processo democrático.

O Ministério Público possui legitimidade para intervir no processo eleitoral, atuando em todas as fases deste processo, quais sejam: inscrição dos eleitores, convenções partidárias, registro de candidaturas, campanhas, propaganda eleitoral, votação, diplomação dos eleitos.

A intervenção do Ministério Público é cabível em todas as instâncias da Justiça Eleitoral, em qualquer época, tanto em período de eleições como fora, podendo se dar como parte autora, quando atua no ingresso de ações judiciais, ou na condição de fiscal, quando, após análise do processo, emite parecer. 
Nos termos do art. 355 do Código Eleitoral, os crimes eleitorais são de ação penal pública, devendo o Ministério Público Eleitoral, presentes os indícios de autoria delitiva e demonstrada a materialidade, oferecer a respectiva denúncia. Caso haja omissão do Promotor Eleitoral, não agindo no prazo legal, cabe ação penal subsidiária, mediante propositura de queixa-crime por parte do ofendido. (MEDEIROS, 2017, p. 148)

Espera-se do Ministério Público, desse modo, total atenção para o processo eleitoral em busca do efetivo alcance dos princípios democráticos.

Nesse sentido, a legalidade eleitoral atuará como uma importante fonte de promoção da cidadania e de sustentação do regime. Torna-se, assim, imperativo zelar pela conformação de um Direito Eleitoral eficiente não apenas na trivial produção da legitimidade de origem, mas também na edificação de um ordenamento embalado por um espírito de justiça que reproduza os ecos gerais do querer coletivo; um modelo em que o produto das eleições celebre e anime o consenso, na medida em que exija muito mais do que o simples respeito às regras do jogo; um Direito Eleitoral em que diplomas cada vez mais inclusivos e moralizadores espraiem-se e ofereçam a tônica. (ALVIM, 2014, p. 31)

\section{CONSIDERAÇÕES FINAIS}

O Estado, ao longo do movimento histórico, passou por intensas transformações até os dias atuais. Com efeito, a Constituição da República de 1988 estabeleceu o Estado brasileiro como Democrático de Direito. Demonstrou, assim, o legislador constitucional, após um período não democrático no país, intensa e correta preocupação com o regime democrático brasileiro.

Estabeleceram-se, em caráter constitucional, os pilares do Ministério Público brasileiro, cabendo-lhe, em especial vertente, a defesa do regime democrático, e, dessa forma, recebeu o alcance de cláusula pétrea, não podendo ser extinto ou diminuído. 
O Ministério Público assumiu, após seu viés constitucional, importante papel no acompanhamento do processo eleitoral brasileiro, agindo como garantidor do regime democrático, devendo prezar pela integral realização da legítima vontade popular.

\section{REFERÊNCIAS BIBLIOGRÁFICAS}

AGUIAR, Claudio Tenorio Figueiredo. O Ministério Público e a implementação de políticas públicas: dever institucional de proteção do núcleo essencial dos direitos fundamentais. In: VILELLA, Patrícia (coord.). Ministério Público e políticas públicas. Rio de Janeiro: Lumen Juris, 2009.

ALMEIDA, Gregório Assagra de. As atribuições e as garantias constitucionais do Ministério Público como cláusulas superconstitucionais, 2007. Disponível em: file:///C:/Users/MPE-TO/AppData/Local/Temp/MPMGJuridico_08.pdf. Acesso em: 27 out. 2020.

O Ministério Público no neoconstitucionalismo: perfil constitucional e alguns fatores de ampliação de sua legitimidade social, 2008. Disponível em http://www.unifafibe.com.br/revistasonline/arquivos/revistajuridicafafibe/sumario/5/1404201 0170607.pdf. Acesso em 26 out. 2020.

ALVIM, Frederico Franco. O direito eleitoral como elo entre a democracia e a representação política. In: Revista Eletrônica EJE - Tribunal Superior Eleitoral. Brasília: ano IV - n. 4, p. 27-31, junho/julho 2014.

BARROS, Vinícius Soares de Campos. O Estado. In NOVELINO, Marcelo; FILHO, Agassiz Almeida. Leituras complementares de direito constitucional - Teoria do Estado. p. 11-35. Salvador: JusPODIVUM, 2009.

BRANDÃO, Paulo de Tarso. Ações constitucionais: novos direitos e acesso à justiça. Florianópolis: Habitus, 2001.

BRASIL. Constituição da República Federativa do Brasil de 1988. Texto compilado. Disponível em: http://www.planalto.gov. br. Acesso em: 24 out. 2020.

DALLARI, Dalmo de Abreu. Elementos de teoria geral do Estado. 19. ed., São Paulo: Saraiva, 1995.

DIAZ, GUSTAVO MERELES RUIZ. A missão constitucional do Ministério Público na defesa do regime democrático: acesso à justiça dos direitos fundamentais. Dissertação (Mestrado acadêmico em Ciência Jurídica) - Universidade do Vale do Itajaí, Programa de Mestrado Acadêmico em Ciência Jurídica, Itajaí, 2007. Disponível em: 
http://www.dominiopublico.gov.br/download/teste/arqs/cp068852.pdf. Acesso em 15 out. 2020.

FILHO, Sylvio Clemente da Motta; SANTOS, Willian Douglas Resinente dos. Direito constitucional. 7. ed. Rio de Janeiro: Impetus, 2000.

GARCIA, Emerson. Exercício de funções eleitorais, pelos promotores de justiça, perante os juízes e juntas eleitorais. Poder de designação do Ministério Público estadual. In: Revista do Ministério Público - Edição comemorativa. Rio de Janeiro, p. 599-607, 2015.

Ministério Público: organização, atribuições e regime jurídico. 2. ed. Rio de Janeiro: Editora Lumen Juris, 2005.

GOULART, Marcelo Pedroso. Ministério Público e democracia: teoria e práxis. Leme: LED, 1998.

JUNIOR, WALLACE PAIVA MARTINS. Ministério Público, democracia e eficiência da atuação. São $2002 . \quad$ Paulo, Disponível em: http://www.revistajustitia.com.br/artigos/zbxz58.pdf. Acesso em 27 out. 2020.

LENZA, Pedro. Direito constitucional esquematizado. 16. ed. São Paulo: Saraiva, 2012.

MAZZILli, Hugo Nigro. O Ministério Público e a defesa do regime democrático. São Paulo, 1997. Disponível em: http://www.mazzilli.com.br/pages/artigos/mpedemocracia.pdf. Acesso em 22 out. 2020.

Manual do promotor de justiça. 2. ed. São Paulo: Saraiva, 1991.

MEDEIROS, Marcílio Nunes. Legislação eleitoral comentada e anotada. Salvador: JusPodivm, 2017.

MORAES, Alexandre de. Direito constitucional. 19. ed. São Paulo: Atlas, 2006.

PALLIERI, Giorgio Balladore. Diritto costituzionale. 4. ed. Milão, Dott. A. Giuffre Editore, 1955.

SILVA. José Afonso da. Curso de direito constitucional positivo. 17. ed. São Paulo: Malheiros, 2000.

Data de Submissão: 10/11/2020

Data de Aceite: 10/12/2020 